\title{
NATURALLY ETCHED TRACKS IN APATITES AND THE CORRECTION OF FISSION TRACK DATING
}

\author{
J.-L. TIEN AND C.-H. CHEN* \\ Department of Geology, National Taiwan University \\ 245 Choushan Road, Taipei 106, Taiwan, R.O.C.
}

\begin{abstract}
Naturally etched tracks have been found in apatites from the rapid cooled, high-level Kunon pluton in the Zhangzhou Igneous Complex, SE China. This is manifested by the fact that the apatite fission track (FT) age derived from conventional counting of spontaneous and induced tracks yields a result of $140.6 \pm 6.5 \mathrm{Ma}$, which is much older than the ages determined using other methods on different minerals from the same rock. When tracks are observed after etching the polished inner sections of the apatite grains, the naturally etched tracks characterized by having hazy boundaries can be distinguished from the normal tracks with sharp boundaries. The age obtained by omitting these fading-resistant hazy tracks, $76.5 \pm 4.0 \mathrm{Ma}$, indicates the time of the Kunon pluton cooling down to $\sim 100^{\circ} \mathrm{C}$. The corrected peak age $(73.8 \mathrm{Ma})$ is consistent with the other apatite FT peak ages $(79.2$ to 70.2 $\mathrm{Ma})$ of the nearly contemporaneous plutons in the same igneous complex.
\end{abstract}

\section{KEYWORDS}

Apatite fission track dating; naturally etched tracks; fading-resistant; high-level plutons.

\section{INTRODUCTION}

Apatite fission tracks are very sensitive to temperature changes. Earlier investigations have shown that the tracks are shortened and the track density is decreased in apatites that experienced paleotemperatures over the range from $20^{\circ} \mathrm{C}$ to at least $125^{\circ} \mathrm{C}$ (e.g. Green et al., 1986). Instead of a single "blocking" temperature value, the wide temperature range with gradually increasing track annealing led to the concept of partial annealing zone (PAZ). A wide distribution of track lengths usually indicates the effect of fading on apatites cooling through the PAZ. However, a similar distribution could also be the consequence of natural etching on tracks. In this study, a rare case that "naturally etched tracks" exist in apatites is reported.

\section{SAMPLING AND METHOD OF ANALYSIS}

Apatites were extracted from the Zudi (ZUD), Punan (PUN), Kunon (KUN), and Yanchian (YNC) granitic bodies in the Zhangzhou Igneous Complex (ZIC), SE China. The field relationship indicates that ZUD and PUN intruded before and YNC emplaced after $\mathrm{KUN} .{ }^{40} \mathrm{Ar} /{ }^{39} \mathrm{Ar}$ ages show that the magmatism for ZIC was most active during 98 to $94 \mathrm{Ma}$ (Tien, 1996). Using the Al-amphibole geobarometer, pressures of these plutons were calculated to be $0.8 \sim 2.1 \mathrm{~kb}$, implying high-level intrusion $(3 \sim 6 \mathrm{~km})$ under rapid cooling conditions $\left(40^{\circ} \mathrm{C} / \mathrm{Ma}\right.$ between $600 \sim 200^{\circ} \mathrm{C}$ ) (Tien et al., 1997).

" Corresponding author, Fax: (+886)-2-23636095, e-mail: chench@ecms.ntu.edu.tw 
The external detector method was used in this work. Ages were calculated by using the zeta calibration approach (Hurford and Green, 1983). The zeta factor used in this study, 317.4 $\pm 20.8(1 \sigma)$, was determined using the standard glass SRM 612 and the age standard Fish Canyon Tuff apatite (Tien, 1996). Track lengths and angles to $c$-axis were measured only for horizontal confined tracks, i.e., those lying on planes approximately parallel to the c-axis of the apatite crystal inclination $\pm 10^{\circ}$.

\section{RESULTS AND DISCUSSION}

\section{Dating and track length measurements}

The results of apatite FT dating and track length measurements are listed in Table 1. The pooled age of KUN apatite (140.6 $16.5 \mathrm{Ma})$ is not only extremely old in comparison with the other plutons in the ZIC, but also unreasonably older than the zircon FT age $(84.7 \pm 2.9 \mathrm{Ma})$, and the ${ }^{40} \mathrm{Ar} /{ }^{39} \mathrm{Ar}$ ages of $\mathrm{K}$-feldspar $(87.5 \pm 1.4 \mathrm{Ma})$, biotite $(93.5 \pm 1.5 \mathrm{Ma})$ and hornblende $(97.9 \pm 2.9 \mathrm{Ma})$ determined on the same sample (Tien, 1996). The age frequency diagram shows a double peak distribution (Fig. 1a), whereas the others have normal distributions (Fig. 2). A total of 97 horizontal confined track lengths measured on KUN apatite distributes into two groups in the angle-to-c-axis versus track-length diagram (Fig. 3). In the standard-deviation versus mean-track-length diagram, the value of KUN apatite is plotted on the area of "bimodal" type (Fig. 4), indicating a two-stage or two-event of cooling.

Table 1. Summary of apatite FT dating of granitic bodies in ZIC and the corrected result of KUN.

\begin{tabular}{|c|c|c|c|c|c|c|c|c|c|c|c|}
\hline \multirow{2}{*}{$\begin{array}{c}\text { Sample } \\
\text { No. }\end{array}$} & \multirow[b]{2}{*}{$\mathrm{N}$} & \multicolumn{3}{|c|}{ Track Density, $\times 10^{6} \mathrm{~cm}^{-2}$} & \multirow[b]{2}{*}{$\underset{(\mathrm{ppm})}{\mathrm{U}}$} & \multirow[b]{2}{*}{$\begin{array}{c}\mathrm{Cl} \\
(w t \%)\end{array}$} & \multirow[b]{2}{*}{$\begin{array}{c}x^{2} \\
\text { test }\end{array}$} & \multirow{2}{*}{$\begin{array}{c}\text { Pooled } \\
\text { Age } \\
(\mathrm{Ma} \pm 1 \sigma)\end{array}$} & \multirow{2}{*}{$\begin{array}{c}\text { Peak } \\
\text { Age } \\
\text { (Ma) }\end{array}$} & \multirow[b]{2}{*}{$\begin{array}{l}\text { Mean track } \\
\text { length }(\mu \mathrm{m})\end{array}$} & \multirow[b]{2}{*}{$\begin{array}{l}\text { S. D. } \\
(\mu \mathrm{m})\end{array}$} \\
\hline & & Standard & Fossil & Induced & & & & & & & \\
\hline YNC & 28 & $\begin{array}{c}2.0125 \\
(2029)^{*}\end{array}$ & $\begin{array}{l}0.3944 \\
(637)^{*}\end{array}$ & $\begin{array}{c}1.7622 \\
(2846)^{*}\end{array}$ & 11.3 & 0.02 & $\mathbf{P}$ & $71.1 \pm 3.5$ & 70.2 & $\begin{array}{c}11.76 \pm 0.28 \\
(100)^{*}\end{array}$ & 2.82 \\
\hline KUN & 28 & $\begin{array}{c}0.9065 \\
(4058)^{*}\end{array}$ & $\begin{array}{l}0.6276 \\
(1026)^{*}\end{array}$ & $\begin{array}{c}0.6353 \\
(1060)^{*}\end{array}$ & 9.0 & 0.15 & F & 140.6 & 132.6 & $\begin{array}{c}10.97 \pm 0.33 \\
(97)^{*}\end{array}$ & 3.21 \\
\hline $\mathrm{KUN}^{+}$ & 29 & $\begin{array}{c}0.9065 \\
(4058)^{*}\end{array}$ & $\begin{array}{l}0.3703 \\
(629)^{*}\end{array}$ & $\begin{array}{c}0.6922 \\
(1176)^{*}\end{array}$ & 9.0 & 0.15 & $\mathrm{P}$ & 76.5 & 73.8 & $\begin{array}{c}12.79 \pm 0.22 \\
(58)^{*}\end{array}$ & 1.72 \\
\hline PUN & 10 & $\begin{array}{c}0.9065 \\
(4058)^{*}\end{array}$ & $\begin{array}{l}0.6179 \\
(164)^{*}\end{array}$ & $\begin{array}{l}1.1416 \\
(303)^{*}\end{array}$ & 16.2 & 0.03 & $\mathbf{P}$ & 77.4 & 72.8 & - & $\cdots$ \\
\hline ZUD & 15 & $\begin{array}{c}2.0125 \\
(2029)^{*}\end{array}$ & $\begin{array}{l}2.8498 \\
(2157)^{*}\end{array}$ & $\begin{array}{l}10.8924 \\
(6962)^{*}\end{array}$ & 69.6 & 0.80 & $\mathbf{P}$ & $83.0 \pm 2.8$ & 79.2 & $\begin{array}{c}14.19 \pm 0.12 \\
(100)^{*}\end{array}$ & 1.17 \\
\hline
\end{tabular}

${ }^{+}$: Corrected, *: track numbers, N: grains, S.D.: standard deviation, $\chi^{2}$ test: Galbraith (1981), P: pass, F: fail.
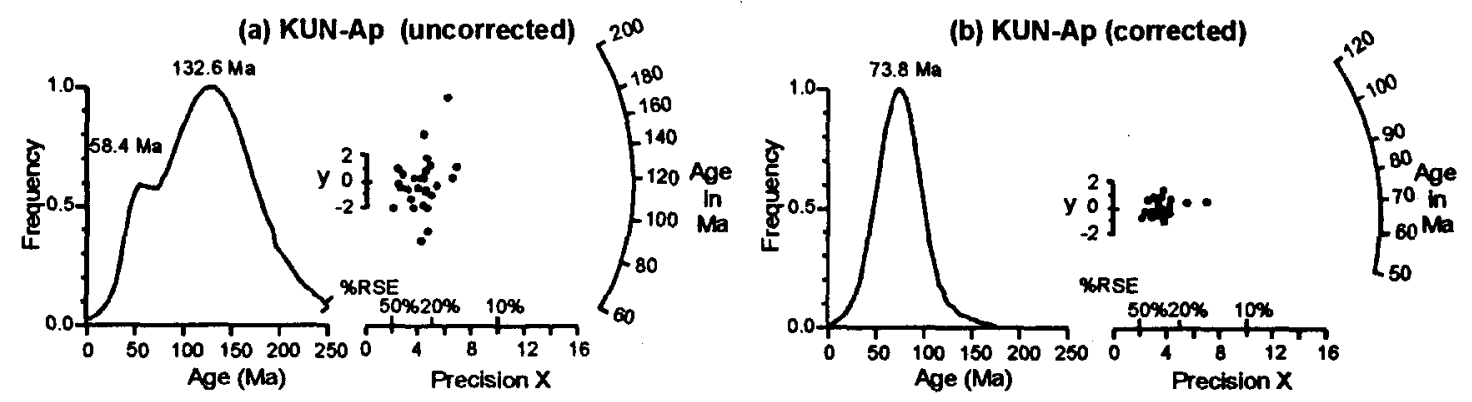

Fig. 1. The age frequency diagrams and radial plots of KUN pluton illustrate the difference between (a) uncorrected and (b) corrected apatite FT dating data.

\section{Naturally etched tracks}

The naturally etched tracks were observed in apatite grains from the KUN monzonitic body, when samples were prepared without any chemical treatment. Morphologically, they have the same 
characteristics as the spontaneous tracks with sharp boundaries, but they are much shorter than the induced tracks in length. The projected lengths of 17 tracks intersecting the etched surface range between 1.36 and $4.88 \mu \mathrm{m}$, with an average of $2.29 \pm 0.97(1 \sigma) \mu \mathrm{m}$.

Two different types of tracks appear in KUN samples after chemical etching. One exhibits sharp boundaries and strong reflection under the microscope (Fig. 5a), while the other shows hazy boundaries (Fig. $5 b$ ). The latter represents those that have been subjected to double etching, the natural one and then the artificial one. When the naturally etched tracks were eliminated from counting, the corrected pooled age thus obtained was $76.5 \pm 4.0 \mathrm{Ma}\left(\mathrm{KUN}^{+}\right.$in Table 1) with a single peak at $73.8 \mathrm{Ma}$ (Fig. 1b), which is rather consistent with the FT peak ages of other plutons in the ZIC (Fig. 2), Mean length $(12.79 \pm 0.22 \mu \mathrm{m})$ and standard deviation $(1.72 \mu \mathrm{m})$ of normal tracks of KUN sample lie on the area of undisturbed basement (Gleadow et al., 1986), corresponding to a monotonic cooling through the PAZ (Fig. 4). On the contrary, the mean length of naturally etched tracks is $8.58 \pm 0.50 \mu \mathrm{m}$ with a standard deviation of $3.09 \mu \mathrm{m}$, indicating that these tracks have been subjected to significant partial annealing before natural etching. It is also noted that the mean track length in ZUD sample is well retained due to high $\mathrm{Cl}$ content (Table $\mathrm{l}$ ).

(a) ZUD-Ap

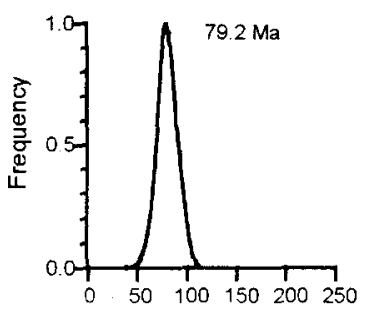

(b) PUN-Ap

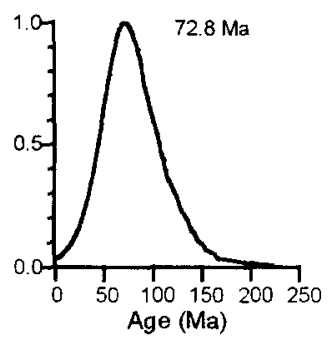

(c) YNC-Ap

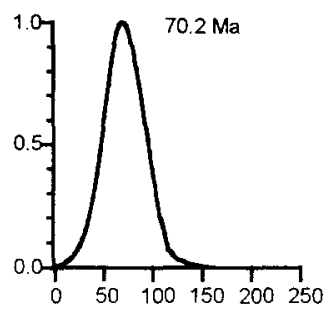

Fig. 2. Age frequency diagrams of apatites from ZUD, PUN and YNC plutons in ZIC

Naturally etched tracks (Fig. 3) became fading-resistant and could be totally preserved in the PAZ and/or the total reset zone. Generally, the proportion of tracks in multiple peaks and separation of apatite in age frequency diagrams depend on factors such as timing, duration and intensity of the thermal events. In the case of KUN pluton, the two-peak distribution (Fig. la) involves one more controlling factor, i.e., the presence of a certain aliquot of naturally etched fading-resistant tracks.

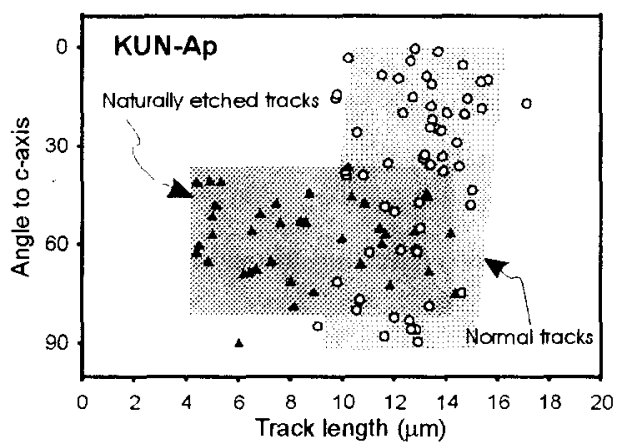

Fig. 3. The distribution field for naturally etched tracks (triangle) is deviated from the normal tracks (circle) in the KUN pluton.

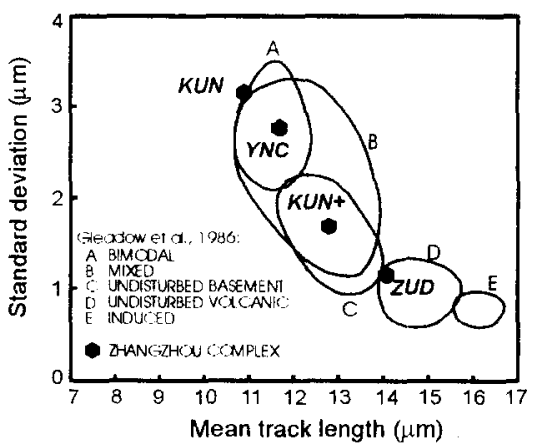

Fig. 4. Standard-deviation vs. Mean-tracklength plots of apatites in ZUD, KUN and YNC plutons.

The cause of naturally etched tracks

The apatite grains containing fading-resistant tracks were inherited from pre-existing rocks. 
Considering only the inherited grains an age of $178.3 \pm 9.5 \mathrm{Ma}$ was obtained, corresponding to an increment of $\sim 100 \mathrm{Ma}$ due to the naturally etched tracks.

The natural etchants attacking the basement rocks may come from the degassing process of ZIC thermal activities occurred shortly before emplacement. This is evidenced by the $\mathrm{Cl} / \mathrm{F}$ ratio in residual apatites (the average of $\mathrm{Cl} / \mathrm{F}$ ratio in $\mathrm{KUN}$ apatites is as low as $0.05 \pm 0.01$ ) as $\mathrm{Cl}$ is more preferentially entering into fluid phase than $\mathrm{F}$ (Brenan, 1994). In addition, a great majority of naturally etched tracks exhibits large angles with respect to the c-axis, conforming with the fact that the natural etchant is more diluted than the artificial one, and only tracks with larger angles were preferentially etched in this case.

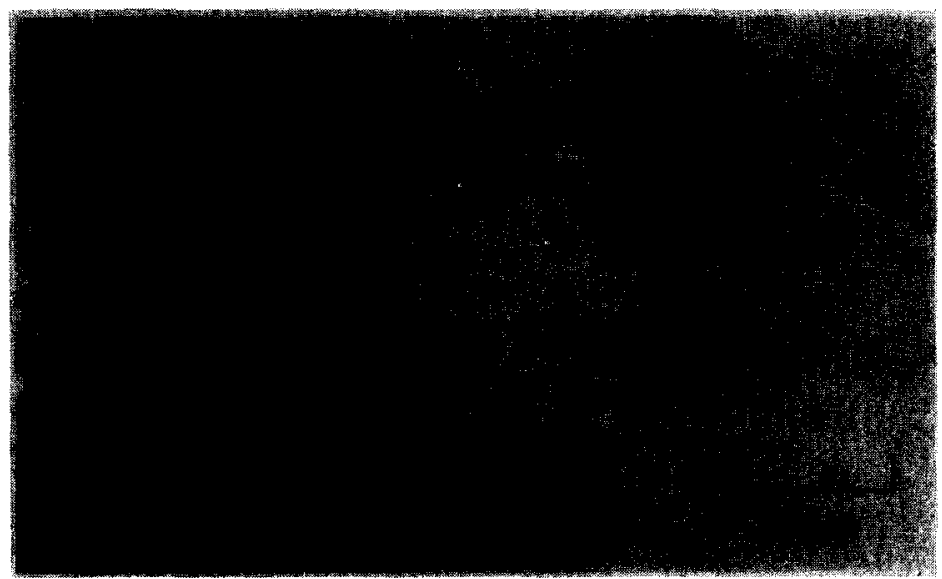

Fig. 5. Morphology of (a) normal and (b) naturally etched tracks in apatite from the KUN high-level pluton.

\section{CONCLUSION}

Possible presence of naturally etched tracks in apatites should be checked when high-level intrusive plutons are dated using the FT method. There are some combining criteria to detect the existence of naturally etched tracks, such as an unexpected old FT age, a small mean-track-length with a large standard deviation, and a characteristic group of tracks concentrated in large angles with respect to the c-axis. A counting procedure conducted by eliminating the fading-resistant tracks allows to determine a cooling age fairly conformable with the normal ones.

\section{REFERENCES}

Brenan J. (1994) Kinetics of fluorine, chlorine and hydroxyl exchange in fluorapatite. Chem. Geol. 110, 195-210.

Galbraith, R.F. (1981) On statistical models for fission-track counts: J. Math. Geol. 13, 471-478.

Gleadow A.J.W., Duddy I.R., Green P.F. and Lovering J.F. (1986) Confined fission track lengths in apatite: a diagnostic tool for thermal history analysis. Contrib. Min. Petrol. 94, 405-415.

Green P.F., Duddy I.R., Gleadow A.J.W. and Laslett G.M. (1986) Thermal annealing of fission tracks in apatite: 1. A qualitative description. Chem. Geol. (Isot. Geosci. Sect.) 59, 237-253.

Hurford A.J. and Green P.F. (1983) The zeta age calibration of fission track dating. Isotope Geosci. 1, 285-317.

Tien J.L. (1996) Comparative Studies of Fission Track Dating and ${ }^{40} \mathrm{Ar} /{ }^{39} \mathrm{Ar}$ Dating of Fujian Late Yanshanian Granitic Complexes, SE China. Ph.D. Thesis, Inst. of Geol., Nat'l Taiwan University, 323PP. (in Chinese).

Tien J.L., Chen C-H., Lo C.H. and Lai Y.S. (1997) Contrasting cooling rates of coeval granitic plutons in the Zhangzhou Igneous Complex, SE China: evidences from ${ }^{40} \mathrm{Ar} /{ }^{39} \mathrm{Ar}$ thermochronology and Al-amplibole geobarometer. J. Geol. Soc. China 40, 607-624. 